\title{
COMPUTATIONAL ANALYSIS BASED ON ARTIFICIAL NEURAL NETWORKS FOR AIDING IN DIAGNOSING OSTEOARTHRITIS OF THE LUMBAR SPINE
}

\author{
Carlos Cassiano Denipotti Veronezi', Priscyla Waleska Targino de Azevedo Simões ${ }^{2}$, Robson Luiz dos Santos ${ }^{3}$, Edroaldo \\ Lummertz da Rocha ${ }^{4}$, Suelen Melão ${ }^{5}$, Merisandra Côrtes de Mattos $^{6}$, Cristian Cechinel ${ }^{7}$
}

\section{ABSTRACT}

Objective: To ascertain the advantages of applying artificial neural networks to recognize patterns on lumbar spine radiographies in order to aid in the process of diagnosing primary osteoarthritis. Methods: This was a cross-sectional descriptive analytical study with a quantitative approach and an emphasis on diagnosis. The training set was composed of images collected between January and July 2009 from patients who had undergone lateral-view digital radiographies of the lumbar spine, which were provided by a radiology clinic located in the municipality of Criciúma (SC). Out of the total of 260 images gathered, those with distortions, those presenting pathological conditions that altered the architecture of the lumbar spine and those with patterns that were difficult to characterize were discarded, resulting in 206 images. The image data base $(n=206)$ was then subdivided, resulting in 68 radiographies for the training stage, 68 images for tests and 70 for validation. A hybrid neural network based on Kohonen self-organizing maps and on Multilayer Perceptron networks was used. Results: After 90 cycles, the validation was carried out on the best results, achieving accuracy of $62.85 \%$, sensitivity of $65.71 \%$ and specificity of $60 \%$. Conclusions: Even though the effectiveness shown was moderate, this study is still innovative. The values show that the technique used has a promising future, pointing towards further studies on image and cycle processing methodology with a larger quantity of radiographies.

Keywords - Osteoarthritis; Artificial Intelligence; Medical Informatics; Diagnosis, Computer-Assisted

\section{INTRODUCTION}

Osteoarthritis (OA) is a joint disorder characterized by pain and functional limitations. An X-ray of osteoarthritis reveals osteophytes and narrowing of the joint spaces, and in the histological tests, changes to the integrity of cartilage and subchondral bone can be observed. This is one of the most common diseases affecting the joints, including the lumbar region. It is of great economic importance, in terms of both productivity and cost of treatment ${ }^{(1-3)}$. In the United States, it is the second largest cause of occupational

1 - Undergraduate Student in Medicine - Universidade do Extremo Sul Catarinense (UNESC), SC, Brazil.


Professor in Medical Informatics at the Universidade do Extremo Sul Catarinense (UNESC), SC, Brazil.

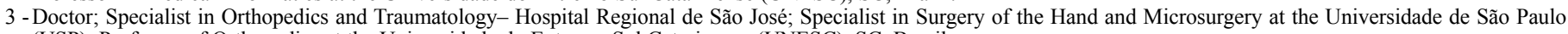
(USP); Professor of Orthopedics at the Universidade do Extremo Sul Catarinense (UNESC), SC, Brazil.

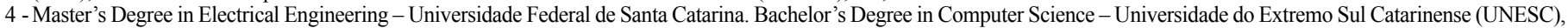
SC, Brazil.

5 - Undergraduate Student in Medicine - Universidade do Extremo Sul Catarinense (UNESC).

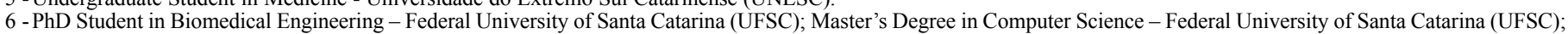
Professor of Artificial Intelligence at the Universidade do Extremo Sul Catarinense (UNESC), SC, Brazil.

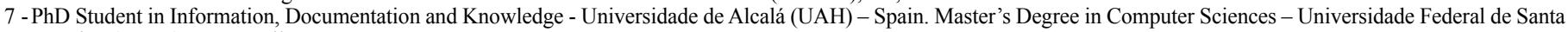
Catarina (UFSC), SC, Brazil.

Work carried out on the Medicine Course - Unidade Acadêmica de Ciências da Saúde - Universidade do Extremo Sul Catarinense (UNESC).

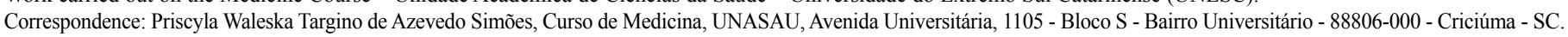

E-mail: pri@unesc.net

Work received for publication: April 18/10; accepted for publication: June 7, 2010 
disability in men aged over 50 , after coronary heart disease. In Brazil, it accounts for about $18 \%$ of the benefits granted by the INSS - the National Institute of Social Security ${ }^{(3)}$. Although its etiology is not yet clearly understood, some risk factors are already known, such as age, weight and occupation ${ }^{(4,5)}$. Studies suggest further research on treatment, which currently only offers relief of pain and improvement of joint function, but does not enable the pathological process to be reversed ${ }^{(6-8)}$.

Therefore, by seeking alternative options for aiding the diagnosis, medical informatics aims to assist doctors in routine diagnoses, and has proven increasingly effective, helping in some clinical tasks, such as warning signs, therapeutic judgments, agents for information retrieval, and image recognition and interpretation, among other models ${ }^{(9-12)}$.

Among the areas of application of medical informatics, artificial intelligence (AI) uses artificial neural networks (ANN) to search for a computational model based on biological neurons which, by means of mathematical models, generates an artificial neuron, and through interconnections of various artificial neurons, generates an ANN. Its importance lies in solving problems that are not easily solved by conventional techniques and tools, such as pattern recognition $^{(13-15)}$; problem solving in classification, prediction, approximation, categorization and optimization; character and voice recognition; and predictions of time series $^{(11,13,16-19)}$.

This study introduces the training, validation and testing of a neural network for the recognition of image patterns of osteophytes of the lumbar spine, in lateral view, in order to assist the diagnosis of primary osteoarthritis of the lumbar spine through imaging techniques.

\section{METHODS}

A cross-sectional, descriptive, analytical study was conducted using a quantitative approach, with diagnostic emphasis. The study was approved by the Human Research Ethics Committee under protocol number 355/2008.

The training set consisted of images of patients who underwent digital radiographies of the lumbar spine in lateral view from January $1^{\text {st }}$ to July $1^{\text {st }}, 2009$, from a radiology service in the municipality of Criciúma (SC). The study consisted of a convenience sample totaling 260 images. Distorted radiographies, pathologies that alter the architecture of the lumbar spine, and patterns that were difficult to characterize were excluded, resulting in 206 images, taken in digital medium in jpg format (so it was not necessary to scan the images). The images were authorized in a term of consent, signed by the person responsible for the company that took the images. The image data base $(n=206)$ was then subdivided, resulting in 68 radiographies used in the training, 68 in the tests, and 70 in the validation.

After collection, the images were processed one by one, as follows: first the contrast was enhanced, and after the use of the first filter, the Euclidean metric was applied. This process was performed for each image. Figure 1 illustrates the results obtained with the use of each filter.

Following this processing, the use of the neural network began; this phase is divided into training, testing and validation. In this phase, an application developed by the Research Group in Applied Computational Intelligence of Universidade do Extremo Sul Catarinense was used, the interface of which can be seen in Figure 2. This software offers a hybrid neural network based on Kohonen's self-organizing maps ${ }^{(20)^{*}}$ and Multilayer Perceptron (MLP) networks.

For the training on Kohonen's network, 68 images were used, corresponding to a subregion of $64 \times 64$ pixels directly selected in the software from the original image; of these, 34 images showed the presence of osteoarthritis and 34 did not. The same image proportions were also used for the testing and validation.

The architecture of the Kohonen's network used for the training consisted of 64 neurons in the input layer and a two-dimensional $8 \times 8$ neuron structure in the Kohonen's layer. The output of this training was then used as input for the trained MLP network, using a backpropagation algorithm, the purpose of which is to classify the resulting map of characteristics as belonging to the group of images with the pattern of osteoarthritis (class 1), or to the group of images without this pattern (class 2).

The architecture of the MLP network used for training and classification of these patterns was set to 64 neurons in the input layer, 45 neurons in the inter- 

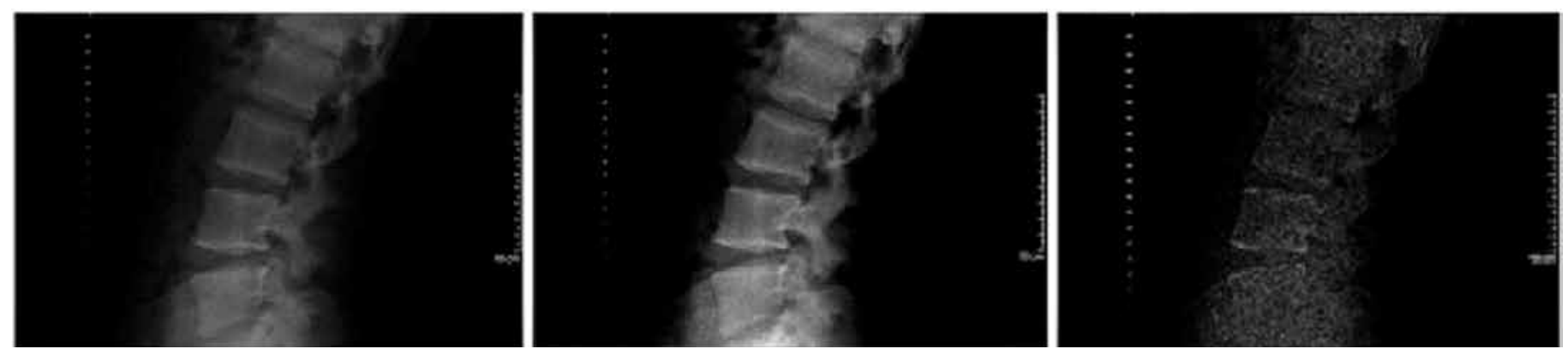

Figure 1 - Image processing.

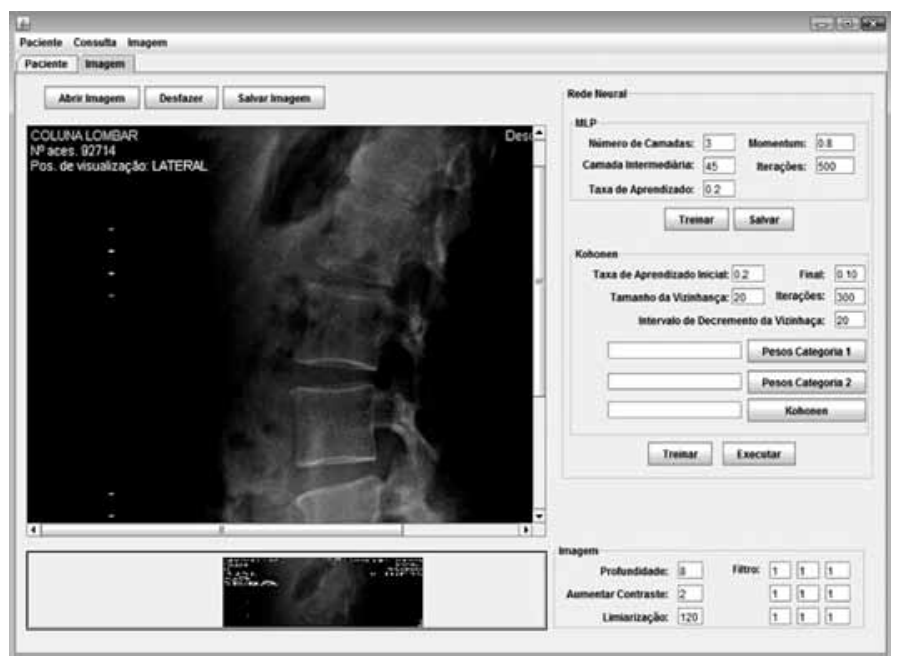

Figure 2 - Application used.

mediate layer and one neuron in the output layer, a learning rate of 0.2 and a momentum of 0.8 with 500 iterations. The structure of the Kohonen's network had an initial learning rate of 0.2 and neighborhood size of 20 , decremented by 20 and final neighborhood size of 0.10 with 300 iterations.

In the statistical analysis, sensitivity, specificity, positive predictive value (PPV), negative predictive value (NPV), positive likelihood ratio (PLR), negative likelihood ratio (NLR), and accuracy of the ANN validation were calculated using the application Microsoft Excel $^{\circledR} 2002$.

\section{RESULTS}

The image data base consisted of 206 images that comprised the set used for the training, testing and validation. For the final ANN result, 90 cycles were performed in the training; the validation was performed using the test of greatest accuracy, which was of $62.85 \%$, with a standard deviation of 4.04 , and the neural network parameters cited in the methodology.
Figure 3 illustrates the variation in accuracy in the top 30 tests.

In a comparison between the test of greatest accuracy and the validation, an increase was observed in the number of accurate validations (Figure 4).

ANN sensitivity was $65.71 \%$ and specificity $60 \%$; positive predictive value was $62.16 \%$ and negative predictive value $63.63 \%$. The calculations showed a positive likelihood ratio of 1.62 and a negative likelihood ratio of 1.72 .

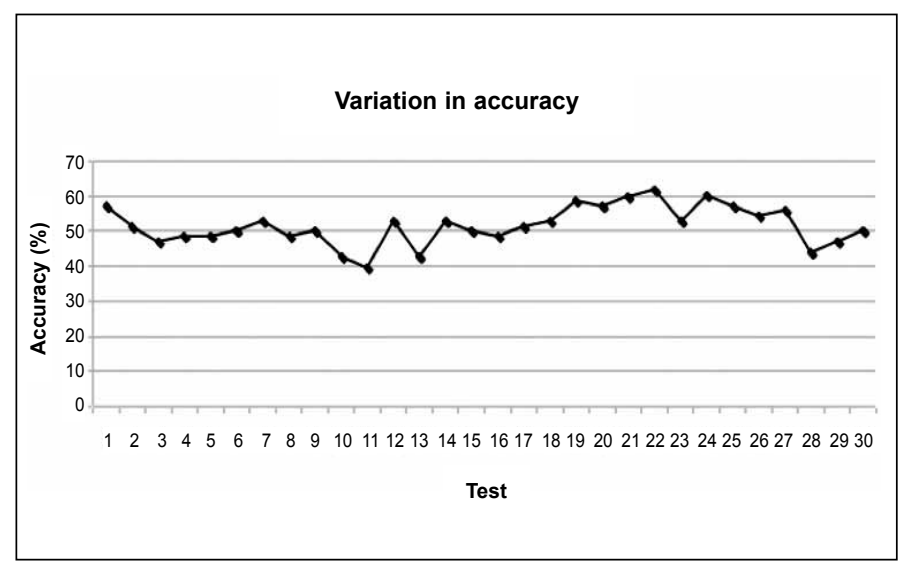

Figure 3 - Variation in accuracy.

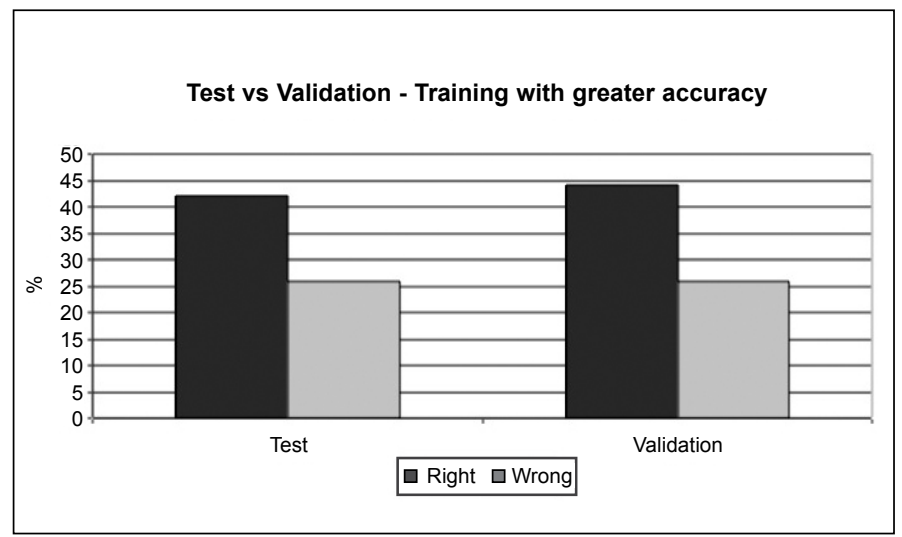

Figure 4 - Comparison between test and validation of neural network. 


\section{DISCUSSION}

Imaging is very important for the diagnosis of osteoarthritis, conventional radiographies being a simple, inexpensive and well-suited method for the identification of that disease, enabling the extent and severity of the disease to be determined, and its progression to be monitored ${ }^{(4)}$. For this article, studies on neural networks from various medical applications were used, including studies using electroencephalograms (EEG); surgical planning; and x-rays of the chest, breast and others.

The accuracy demonstrated by the ANN in this study was $62.85 \%$, which is below the average found in the literature (around 85\%) $)^{(16,21-25)}$. An example is the study carried on in São Luiz (MA) ${ }^{(25)}$, in 2009, on the surgical planning of strabismus, which had an accuracy of $83 \%$. This result may be due to the characterization of the images since, because they are digital radiographies, a wide variation can be found in their patterns.

Sensitivity (65.71\%) and specificity (60\%) were also lower compared to previous ANN studies, as in the study carried on at the Universidade Federal do Paraná in $2009^{(26)}$, which showed an average sensitivity and specificity of $90 \%$ in EEG patterns. The high false-positive rate (14) and false-negative rate (12) can be explained by the limited number of images used for the network training $(n=68)$, even though some studies present higher accuracy with the same number of images ${ }^{(13)}$.

PPV and NPV were $62.16 \%$ and $63.63 \%$, respectively, with values lower than those of litera- ture, which resulted in an average of $90 \%$ in these calculations $^{(26)}$.

The likelihood ratio evaluates the quality of a diagnostic test; however, no studies addressing this calculation for pattern recognition in images using artificial neural networks have been found to date. The present study shows an PLR of 1.62, which means that the positive result obtained for the network is 1.62 times more likely to be actually positive compared with the negative cases.

\section{CONCLUSIONS}

This article addresses the use of a support system for the diagnosis of osteoarthritis of the lumbar spine, based on images from digital radiographies of the lumbar spine in lateral view. Sensitivity and specificity were around $63 \%$. Therefore further tests with a larger amount of images of patients with or without OA should be performed, and the methodology used in image processing should be improved, aiming to obtain greater accuracy of the system. Although the neural network presented an average efficacy, because this was an innovative study, its results show a potential for the use of computer-based artificial neural networks to assist and support practitioners.

It should be highlighted that the use of computers to assist in the analysis of $\mathrm{x}$-ray images has proven effective for diagnosis in different medical specialties, therefore high accuracy is not initially required but rather, a performance closer to that of experts, to support them, not to replace them ${ }^{(12)}$, seeking also to help in the process of medical education.

\section{REFERENCES}

1. Pye SR, Reid DM, Lunt M, Adams JE, Silman AJ, O'Neill TW. Lumbar disc degeneration: association between osteophytes, end-plate sclerosis and disc space narrowing. Ann Rheum Dis. 2007;66(3):330-3.

2. Silva NA, Marczyk LR. Eficácia e tolerabilidade da nimesulida versus celecoxib na osteoartrite. Acta Ortop Bras. 2001;9(1):42-54.

3. Silva Junior FS. Osteoartrite experimental em ratos: efeito do sulfato de glicosamina e sulfato de condroitina sobre a incapacitação articular e a lesão da cartilagem articular [tese]. São Paulo: Faculdade de Medicina da Universidade de São Paulo; 2007.

4. Hinton R, Moody RL, Davis AW, Thomas SF. Osteoarthritis: diagnosis and therapeutic considerations. Am Fam Phys. 2002;65(5):841-8.
5. Hassett G, Hart DJ, Manek NJ, Doyle DV, Spector TD. Risk factors for progression of lumbar spine disc degeneration: the Chingford study. Arthritis Rheum. 2003;48(11):3112-7.

6. Faloppa F, Belloti JC. Tratamento clínico da osteoartrose: evidências atuais. Rev Bras Ortop. 2006;41(3): 47-53.

7.Coimbra IB, Pastor EH, Greve JM, Puccinelli MLC, Fuller R, Cavalcanti FS, et al. Osteoartrite (artrose): tratamento. Rev Bras Reumatol. 2004;44(6):450-3.

8. Coimbra IB, Pastor EH, Greve JMD, Puccinelli ML, Fuller R, Cavalcanti FS, et al. Consenso Brasileiro para o Tratamento da Osteoartrose. Rev Bras Reumatol. 2002;42(6):371-4. 
9. Westphal JT. Modelagem Difusa de um Sistema Especialista Médico: Avaliação dos fatores de Interação em Crianças Queimadas [dissertação]. FlorianópolisSC: Universidade Federal de Santa Catarina; 2003.

10. Motta DN. Uma proposta para o ensino de Informática em Saúde na Residência Médica". Brasília Médica; 1999;36(3/4):110-7.

11. Dias CG, Radonsky V. Desenvolvimento de um sistema de auxílio ao diagnóstico em pediatria com o uso de redes neurais artificiais. Rev Exacta (São Paulo). 2003;1:89-95.

12. Azevedo-Marques PM. Diagnóstico auxiliado por computador na radiologia. Radiol Bras. 2001;34(5):285-93

13. Tarallo AS. Segmentação e classificação de imagens digitais de úlceras cutâneas através de redes neurais artificiais [dissertação]. São Carlos: Universidade Federal de São Carlos; 2007.

14. Rodrigues FA. Localização e reconhecimento de placas de sinalização utilizando um mecanismo de atenção visual e redes neurais artificiais [dissertação] Universidade Federal de Campina Grande; 2002.

15. Bianchini AR. Arquitetura de redes neurais para o reconhecimento facia baseado no neocognitron [dissertação]. São Carlos: Universidade Federal de São Carlos; 2001.

16. Souza MB, Tomikawa VO, Oliveira BF, Polati M. Uso da rede neural artificial no planejamento cirúrgico da correção do estrabismo. Arq Bras Oftalmol. 2004;67(5):459-62.

17. Goulart DA, Tacla MA, Marback PMF, Sole D, Paranhos Junior A, Perez HB, et al. Redes neurais artificiais aplicadas no estudo de questionário de varredura para conjuntivite alérgica em escolares. Arq Bras Oftalmol. 2006;69(5):707-3.

18. Penna MLF. Rede neural artificial para detecção de sobremortalidade atribuível à cólera no Ceará. Rev Saúde Pública. 2004;38(3):351-7.

19. Santos MA, Seixas JM, Pereira BB, Medronho RA. Usando redes neurais ar- tificiais e regressão logística na predição da hepatite A. Rev Bras Epidemiol. 2005;2(8):117-26.

20.Rogers J. Object-oriented neural networks in C++. California: Academic Press; 1997.

21. Argoud FIM, Azevedo FM, Neto MJ. Sistema de detecção automática de paroxismos epileptogênicos em sinais de eletroencefalograma, Rev Bras Controle Autom. 2004;15(4):467-75.

22. Cunha FL, Franca JEM, Ortolan RL, Junior Cliquet $A$. O uso de redes neurais artificiais para o reconhecimento de padrões em uma prótese mioelétrica de mão. VIII Congresso Brasileiro de Redes Neurais; out 2007; Florianópolis-SC. Available at: http://www.sel.eesc.sc.usp.br/labciber/alunos pos/ortolan/arquivos/ p339.PDF

23. Glingani FA, Ambrósio PE. Sistema de análise computadorizada para auxílio à detecção de lesões de mama baseado em redes neurais artificiais. XXIX Congresso da Sociedade Brasileira de Computação; Jul 2009; Bento Gonçalves-RS. Available at: http://www.sbis.org.br/cbis9/arquivos/553.pdf

24. Valini RA, Ambrósio PE, Azevedo-Marques PM. Redes neurais artificiais de Kohonen na caracterização de lesões intersticiais em radiografias pulmonares. VIII Congresso Brasileiro de Redes Neurais; out 2007; Florianópolis-SC. Available at: http://www.sbis.org.br/cbis/arquivos/972.pdf

25. Almeida JDS, Silva AC, Paiva AC, Teixeira JAM. Metodologia computacional para detecção e diagnóstico automáticos, e planejamento cirúrgico do estrabismo. XXIX Congresso da Sociedade Brasileira de Computação; Jul 2009; Bento Gonçalves-RS. Available at: http://bibliotecadigital.sbc.org.br/?module=Pu blic\&action=Publication Object\&subject=364\&publicationobjectid=144

26. Sovierzoski MA, Schwarz L, Azevedo FM. Identificação em Sinais de EEG de Eventos Epileptiformes e da Piscada Palpebral com um Classificador Neural Binário. XXIX Congresso da Sociedade Brasileira de Computação; Jul 2009; Bento Gonçalves-RS. Available at: http://portal.sbc.org.br/bibliotecadigital/?m odule=Public\&action=SearchResult\&author $=2761$ 